\title{
Allelopathic Effects of Purple Nutsedge Extract on the Physiological Quality of Cabbage and Tomato Seeds
}

\author{
Gabriel Pereira de Souza ${ }^{1}$, Isa Anastacia Borges ${ }^{1}$, Cleiton Gredson Sabin Benett ${ }^{2}$, Érica Fernandes Leão-Araújo ${ }^{1}$, \\ Carmen Rosa da Silva Curvêlo ${ }^{1} \&$ Katiane Santiago Silva Benett ${ }^{2}$ \\ ${ }^{1}$ Federal Institute Goiás, Campus Urutaí, Urutaí, Goias, Brazil \\ ${ }^{2}$ State University of Goiás, Campus Ipameri, Ipameri, Goias, Brazil \\ Correspondence: Cleiton Gredson Sabin Benett, Department of Agronomy, State University of Goiás, Ipameri, \\ Goias, Brazil. Tel: 55-(64)-3491-1556. E-mail: cleiton.benett@gmail.com
}

Received: June 5, 2019

doi:10.5539/jas.v11n17p260
Accepted: September 10, $2019 \quad$ Online Published: October 15, 2019

URL: https://doi.org/10.5539/jas.v11n17p260

\begin{abstract}
Invasive plants may present allelopathic substances that interfere with the germination and initial development of seedlings of various species. The objective of this study is to evaluate the physiological quality of cabbage and tomato seeds in the presence of different concentrations of purple nutsedge extract. The seeds were left to germinate in different substrates. Individual experiments were performed for both species. Five concentrations $(0$, 25, 50, 75 and 100\%) of aqueous extract obtained from tubers of Cyperus rotundus were used. The seeds of each species were placed to germinate in three types of substrates (sand, commercial, and paper). Germination, normal seedlings, abnormal seedlings, non-germinated seeds, germination speed index, and accelerated aging were evaluated. A completely randomized experiment with a $3 \times 5$ factorial design (three substrates and five concentrations of purple nutsedge extract) was conducted with four replications. For the substrates, the means were compared by Tukey test at 5\% probability. Polynomial regression analyses were carried out for concentrations of purple nutsedge extract. Cyperus rotundus exerts allelopathic effects on the germination of tomato and cabbage seeds. As the concentration of the tuber extract increases, the inhibitory effect increases, thus reducing germination and seed vigor in the different substrates. The commercial substrate for tomato and the paper substrate for cabbage may minimize the allelopathic effects of Cyperus rotundus extract during germination of seeds.
\end{abstract}

Keywords: Brassica oleracea; Lycopersicon esculentum Mill.; Cyperus rotundus; allelopathy; germination.

\section{Introduction}

Horticulture plays an important role in the Brazilian economy and in Brazilian agriculture. However, the high incidence of weeds has become one of the main obstacles to a high productivity in the cultivation of oleraceous due to the difficulty of control. Thus, it is important to seek new management alternatives to increase production, such as knowledge of plants that may exert some allelopathic effect on the germination and early development of other species, enabling the producer to develop strategies that may lead to the success of production.

The interference from invasive plants in crops of commercial interest happens because of competition for water, light, carbon dioxide and nutrients, and because of allelopathic effects, causing a qualitative and quantitative decrease in production (Bianchi, 1995).

According to Panozzo et al., purple nutsedge (Cyperus rotundus) is a perennial weed that causes damage to several commercial crops due to its fast reproduction and dissemination allied to difficulty of control.

The tubers of purple nutsedge remain dormant in the soil for long periods, as it has an irregular dormancy (Jakelaitis et al., 2003). They have substances whicth exert an allelopathic activity in the presence of some cultivated species (lettuce, rucula, carrot). They also exert insecticidal and repellent effects on arthropods (Durigan et al., 2005).

Allelopathy is the direct or indirect effect that one plant exerts on another through the exudation of chemical compounds (saponins, tannins and flavonoids) released into the environment (S. J. H. Rizvi \& H. Rizvi, 1992; Pires et al., 2001). Such chemicals have the ability to interfere with seed germination and plant development. 
However, the most used procedure during the initial phase of prospecting allelopathic activities of a certain plant is the use of crude extracts. For example, Andrade et al. (2009), evaluating the allelopathic potential of dry leaves of purple nutsedge on seed germination, observed that the aqueous extracts did not decrease the germination percentage of tomato and lettuce seeds, but the germination of seeds of mustard, broccoli, cauliflower, cabbage, turnip, and radish were affected by the extracts.

In addition to the use of the extract of purple nutsedge in the germination, it is necessary to observe the type of substrate in this phase, where each type can influence the physiological response of seeds positively or negatively. The study on the influence of different substrates on the germination of species of interest is advisable because the physiological response of seeds varies according to the different substrates used (Stockman et al., 2007). The allelopathic effect may also occur on the substrate type, as this exerts influence on the availability of water to the seeds during the germination process. The main function of the substrate is to provide support and maintain adequate conditions for seedling germination and development (Moraes et al., 2007; Cunha et al., 2006).

The objective of this study is to evaluate the physiological quality of cabbage and tomato seeds in the presence of different concentrations of purple nutsedge extract left to germinate in different substrates.

\section{Material and Methods}

\subsection{Location}

The experiments were carried out at the Seeds Laboratory of the Instituto Federal Goiano, Campus Urutaí. The tomato "Rio Grande Ripe" and cabbage "Crazy Summer" seeds were purchased from the agricultural trade of the region and analyzed in individual experiments. The seeds "Rio Grande Ripe" with a germination of 93\% and a purity of $99.9 \%$, and "Crazy Summer" with a germination of $81 \%$ and a purity of $99.8 \%$, both of the brand ISLA $^{\circledR}$.

\subsection{Statistical Design and Plant Materials}

For the preparation of the aqueous extract, tubers of Cyperus rotundus L. were removed from plants that had the same development cycle. The tubers were cleaned, washed in running water, and ground in a blender containing distilled water. Then, the solution was filtered on filter paper. The extract was prepared according to Bolzan (2003). At the $100 \%$ concentration, $100 \mathrm{~g}$ of tubers per liter of distilled water were used, constituting a stock solution to obtain the other concentrations. The extract was diluted in three more doses, and distilled water was used as the control treatment $(0 \%)$. Five concentrations of purple nutsedge extract $(0,25,50,75$, and $100 \%)$ were then used, and the filtered crude extract was used for the concentration $100 \%$.

The extract of purple nutsedge at the different concentrations was used to moisten the substrates and perform the tests of physiological quality of seeds. The substrates were filter paper for germination, Maxfertil ${ }^{\circledR}$ commercial substrate, and sand. The filter paper for germination was previously moistened with the equivalent in $\mathrm{mL}$ to 2.5 times the mass of the dried paper. The commercial substrate and the sand were moistened as described for procedures for wetting sand in Brasil (2009), i.e., using $60 \%$ of the field capacity of the substrate.

\subsection{Evaluated Characteristics}

Germination, normal seedlings, abnormal seedlings, non-germinated seeds, germination speed index, and accelerated aging were evaluated as described below.

Germination: for each experiment, four replicates of 50 seeds, seeded in gerbox acrylic boxes, were performed. The three wetted substrates were used as previously described. The boxes were kept in a Mangelsdorf germinator at constant $25{ }^{\circ} \mathrm{C}$ for the experiment with tomato and at constant $20^{\circ} \mathrm{C}$ for the experiment with cabbage. The evaluations occurred at ten and 14 days after sowing for cabbage and tomato, respectively. All seeds in which at least root protrusion occurred were considered germinated. The results were expressed as percentage.

Normal and abnormal seedlings and non-germinated seeds: determined by the germination test. Seedlings were considered normal when they showed the potential to continue their development and give rise to normal plants. The other seedlings were considered abnormal. The non-germinated seeds were hard, dead or dormant, that is, there was no seedling formation. Evaluations occurred on the same date of germination, and the results were expressed as percentage.

Germination speed index: counts of germinated seeds were made every 24 hours, that is, seeds in which there was at least root protrusion. The counts were performed until the date established for the germination test. For the calculation, the formula proposed by Maguire (1962) was used. 
Accelerated aging: the test was performed according to the gerbox method and Marcos Filho (1999). For each experiment, four replicates of 50 seeds were used for each treatment. The gerbox boxes were kept in a chamber regulated at $42{ }^{\circ} \mathrm{C}$, where they remained for 72 hours. After this period, the seeds were submitted to the germination test as previously described.

Two experiments were carried out: tomato and cabbage. A completely randomized experiment with a $3 \times 5$ factorial design (three substrates and five concentrations of purple nutsedge extract) was conducted with four replications.

\subsection{Statistical Analysis}

The results were submitted to analysis of variance (F test). For the substrates, the means were compared by Tukey test at $5 \%$ probability. Polynomial regression analyses were carried out for concentrations of purple nutsedge extract. The statistical analyses were performed using the software Statistical Analysis (Sanest).

\section{Results and Discussions}

\subsection{Tomato}

All characteristics were statistically significant for both sources of variation singularly, with a significant interaction of substrates and concentrations of purple nutsedge extract for evaluations of normal seedlings and abnormal seedlings (Table 1).

Table 1. Summary of analysis of variance of the physiological quality of seeds tested for germination (G), normal seedlings (NS), abnormal seedlings (AS), non-germinated seeds (NGS), germination speed index (SPI), and accelerated aging (AA) in function of substrate and concentration of purple nutsedge extract in tomato

\begin{tabular}{llllllll}
\hline \multirow{2}{*}{ Source of variation } & \multicolumn{7}{c}{ P value } \\
\cline { 2 - 7 } & DF & G & NS & AS & NGS & GSI & AA \\
\hline Substrate (S) & 2 & $<0.01^{* *}$ & $<0.01^{* *}$ & $<0.01^{* *}$ & $<0.01^{* *}$ & $<0.01^{* *}$ & $<0.01^{* *}$ \\
Concentration (C) & 4 & $<0.01^{* *}$ & $<0.01^{* *}$ & $<0.01^{* *}$ & $<0.01^{* *}$ & $<0.01^{* *}$ & $<0.01^{* *}$ \\
S $\times$ C & 8 & $0.09^{\text {ns }}$ & $0.0138^{*}$ & $0.0218^{*}$ & $0.098^{\text {ns }}$ & $0.1^{\text {ns }}$ & $0.908^{\text {ns }}$ \\
\cline { 2 - 8 } & \multicolumn{7}{c}{ Mean squares } \\
Residue & 45 & 70.39 & 123.46 & 49.32 & 70.39 & 0.35 & 66.77 \\
Mean & - & 75.75 & 56.33 & 19.41 & 24.25 & 5.41 & 14.28 \\
CV (\%) & - & 11.0 & 19.72 & 36.17 & 34.59 & 11.1 & 34.21 \\
\hline
\end{tabular}

Note. * Significant by $\mathrm{F}$ test $(\mathrm{P}<0.05) ; * *$ Significant by $\mathrm{F}$ test $(\mathrm{P}<0.01) ;{ }^{\text {ns }}$ not significant.

For the normal seedlings, the interaction was significant and the effects of extract concentrations resulted in a non-linear fitting for all tested substrates (Figure 1A). The percentage of normal seedlings decreased as the concentration of purple nutsedge extract increased. According to ISTA (2018), for a seedling to be considered normal, it must be intact, that is, all essential structures should be well developed, complete, proportionate, and healthy. Seedlings with small defects in their essential structures are also classified as normal, provided that the seedling has a satisfactory and balanced development when compared to the intact seedling. Thus, the capacity of normal seedling formation depends on the test conditions. In this work, the extract of purple nutsedge was responsible for impairing the development of seedlings.

For the normal seedlings at concentrations of purple nutsedge extract higher than $50 \%$, the sand substrate resulted in the lowest percentages. Possibly, due to the availability of the extract to the seeds and seedlings in the sand substrate, which has chemical and physical properties different from the other two, such as increased porosity and aeration, the effects of the extract on this substrate are potentiated. Gomes et al. (2016), evaluating extract of tubers of purple nutsedge in different substrates on the physiological quality of lettuce and rocket seeds, observed that the germination was influenced by the application of the extract $(0,25,50,75$, and $100 \%)$ in different substrates. The sand substrate had the lowest percentage of germination in relation to the other substrates tested.

When evaluating abnormal seedlings, the interaction was significant only for the paper and sand substrates (Figure 1B). For these substrates, there was a positive linear regression fitting, that is, the more concentrated the purple nutsedge extract, the greater the percentage of abnormal seedlings. Then, the extract of purple nutsedge, according to the increase in concentration, resulted in compromising the development of seedlings. According to 
ISTA (2018), seedlings are classified as abnormal when they present defects that compromise the development of the plant, and cause damaged, deformed or deteriorated seedlings.
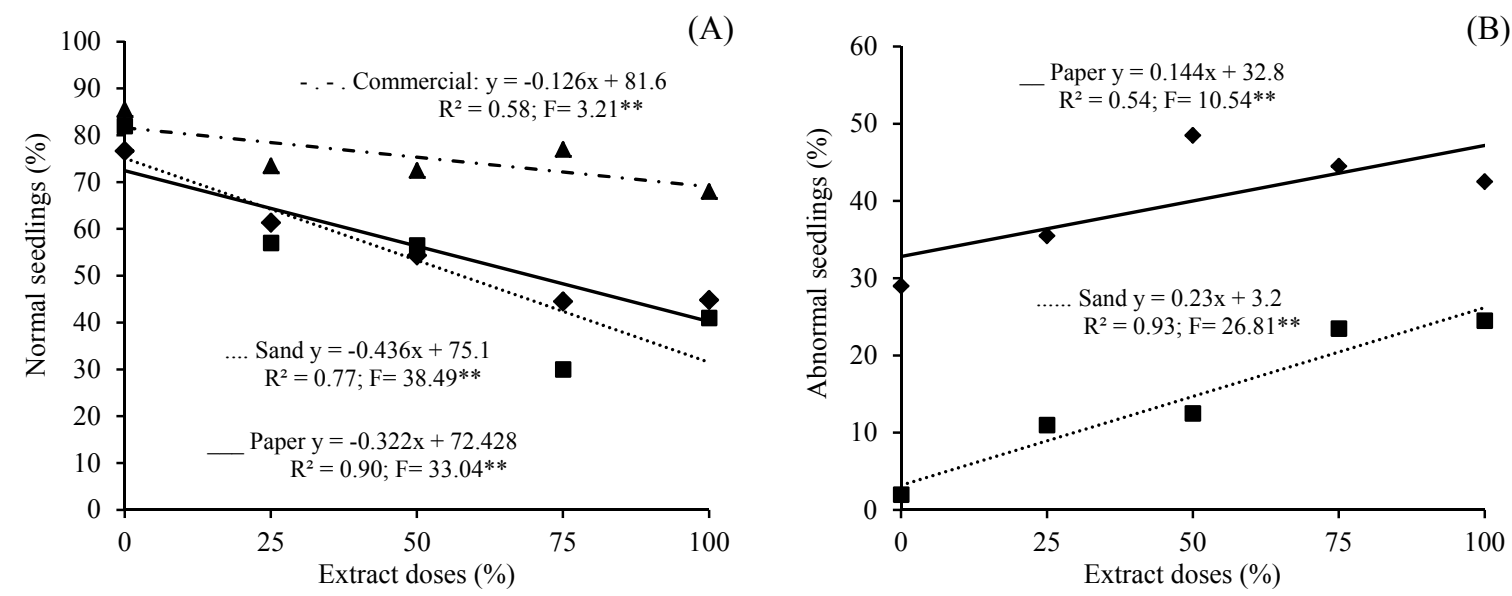

Figure 1. Normal seedlings (A) and abnormal seedlings (B) in function of substrate type and concentration of tomato extract

Note. ${ }^{* *}$ Significant by $\mathrm{F}$ test $(\mathrm{P}<0.01)$

The results evidence that the extract from tubers of purple nutsedge plants exerts decreasing or inhibiting effects on the germination process, reducing the total number of normal seedlings formed and increasing the percentage of abnormal seedlings in all substrates tested, possibly by the presence of allelopathic substances. The most common substances that cause allelopathic effects belong to the groups of phenolic acids, coumarins, terpenoids, alkaloids, cyanogenic glycosides, benzoic acid derivatives, ethylene, saponins, tannins, complex quinones and flavonoids (Souza \& Furtado, 2002; Tokura \& Nóbrega, 2006).

This fact was also observed by Muniz et al. (2007), who proved the negative interference of extracts of purple nutsedge in the physiological quality and the activity of enzymes involved in the germination process of corn, beans, soybean, and lettuce seeds. Some examples of these enzymes are esterase, malate dehydrogenase, alcohol dehydrogenase, superoxide dismutase, catalase and endo- $\beta$-mannanase.

By evaluating the effects of the substrates alone, a significance was observed for all variables evaluated (Tables 1 and 2). For germination and germination speed index, the paper substrate and the commercial substrate were superior to the sand substrate: 18.23 and $15.95 \%$ higher, respectively (Table 2). For the variable non-germinated seeds, the same tendency was observed, with a superiority for the paper and commercial substrates.

Table 2. Germination (G), normal seedlings (NS), abnormal seedlings (AS), non-germinated seeds (NGS), germination speed index (GSI), and accelerated aging (AA) in function of substrate and concentration of purple nutsedge extract in tomato

\begin{tabular}{|c|c|c|c|c|c|c|}
\hline Substrate & G & NS & AS & NGS & GSI & AA \\
\hline & \multicolumn{5}{|c|}{----------------------------- \% } & ---- \% ---- \\
\hline Paper & $80 \mathrm{a}$ & $40 \mathrm{c}$ & $40 \mathrm{c}$ & $20 \mathrm{a}$ & $5.75 \mathrm{a}$ & $15 \mathrm{~b}$ \\
\hline Commercial & $79 \mathrm{a}$ & $75 \mathrm{a}$ & $4 \mathrm{a}$ & $21 \mathrm{a}$ & $5.63 \mathrm{a}$ & $39 \mathrm{a}$ \\
\hline Sand & $68 \mathrm{~b}$ & $53 \mathrm{~b}$ & $15 \mathrm{~b}$ & $32 \mathrm{~b}$ & $4.86 \mathrm{~b}$ & $31 \mathrm{a}$ \\
\hline F Value & 12.96 & 50.44 & 141.43 & 12.96 & 13.06 & 11.38 \\
\hline $\mathrm{CV}(\%)$ & 11.07 & 19.72 & 36.17 & 34.59 & 11.06 & 34.21 \\
\hline
\end{tabular}

Note. Means followed by the same lowercase letter in columns do not differ by Tukey test at $5 \%$ probability.

For accelerated aging, the best performance of seeds occurs in the sand and commercial substrates in detriment to the paper substrate. For the variables normal seedlings and abnormal seedlings, the commercial substrate was 
superior for the development of seedlings, followed by the sand substrate, classified as intermediate, and finally the paper substrate, with inferior results.

After exposure of the seeds to the accelerated aging test, the high humidity of this test favors the appearance of fungi that may compromise the germination process and seedling formation. In sand and commercial substrates there is greater dispersion of fungi and less contact with the structure of seeds and seedlings. On paper the development of fungi is favored and the contact impairs the process of germination and emergence (Henning, 1994).

According to Stockman et al. (2007), it is important to know the influence of the substrate on the physiological quality of seeds since the germination can be influenced by the substrate. Elements such as water retention capacity, degree of pathogen infestation and aeration may vary from one substrate to another, directly influencing seed germination. The main function of a substrate is to provide support and maintain adequate conditions for seedling germination and development (Moraes et al., 2007; Cunha et al., 2006).

In general, the commercial substrate is superior than sand and paper. This is because this substrate presents satisfactory texture and structure requirements for the development of seedlings, since it was developed for this purpose. According to Hartmann et al. (1997), the substrates must present texture and structure aspects suitable for germination, as well as a good composition of the solid, liquid and gas phases, which will guarantee a favorable performance of the seed germination process. According to the authors, sand does not present colloidal properties. This may explain the fact that the commercial substrate presented more promising results than the sand substrate in this research.

The inferior results observed for the paper substrate than the sand and commercial substrates, may be related to the occurrence of phytotoxicity in seedlings. According to ISTA (2018), seedlings may present such symptoms in this substrate. In these cases, other substrate types, such as sand and soil, should be alternatively tested.

The evaluation of individual effects of extracts of purple nutsedge on seed quality showed that, for germination and germination rate, the values fitted the non-linear regression, that is, the higher the concentration of the extract, the lower the result for these variables (Figures 2A and 2B). These results corroborate with Ferreira and Aquila (2000), who observed an allelopathic effect of the extract of purple nutsedge on the initial growth of rice seedlings. In addition, Castro et al. (1983) have already reported that aqueous extracts from the underground part of Cynodon dactylon (L.) Pers. (Bermuda grass), Cyperus rotundus L. (purple nutsedge) and Sorghum halepense (L.) Pers. (Johnson grass) inhibited the germination and growth of tomato.

Andrade et al. (2009), studying aqueous extracts of leaves of purple nutsedge, showed that there was no decrease in the percentage of germination in lettuce and tomato seeds in the presence of aqueous extracts compared to the control treatment. Therefore, the aqueous extract of purple nutsedge tubers may present a greater capacity to inhibit germination or to impair the development of tomato seedlings.

When non-germinated seeds were evaluated, the values fitted a positive linear regression: as the concentration of purple nutsedge extract increased, non-germinated seeds increased (Figure 2C). This fact confirms the allelopathic potential of the extract and demonstrates that the increased concentrations of this extract cause deleterious effects on seeds. Coelho et al. (2014) obtained similar results. The authors tested the aqueous and ethanolic extracts of purple nutsedge. They observed that the application of ethanolic extracts inhibited the germination of bean seeds.

For accelerated aging, the values fitted a linear regression: as the concentration of purple nutsedge extract increased, the germination percentage of seeds subjected to accelerated aging test decreased (Figure 2D). The accelerated aging test is a vigor test that estimates seed vigor and storage potential. This test includes seed exposure to stress conditions, such as a high relative humidity and a high temperature, and evaluates seed performance after these conditions cease. Thus, seeds that are more vigorous will result in a higher percentage of germination after aging (Marcos-Filho, 2015). The purple nutsedge extract negatively affected the possibility of a good response after the stress of seeds during the accelerated aging test. 

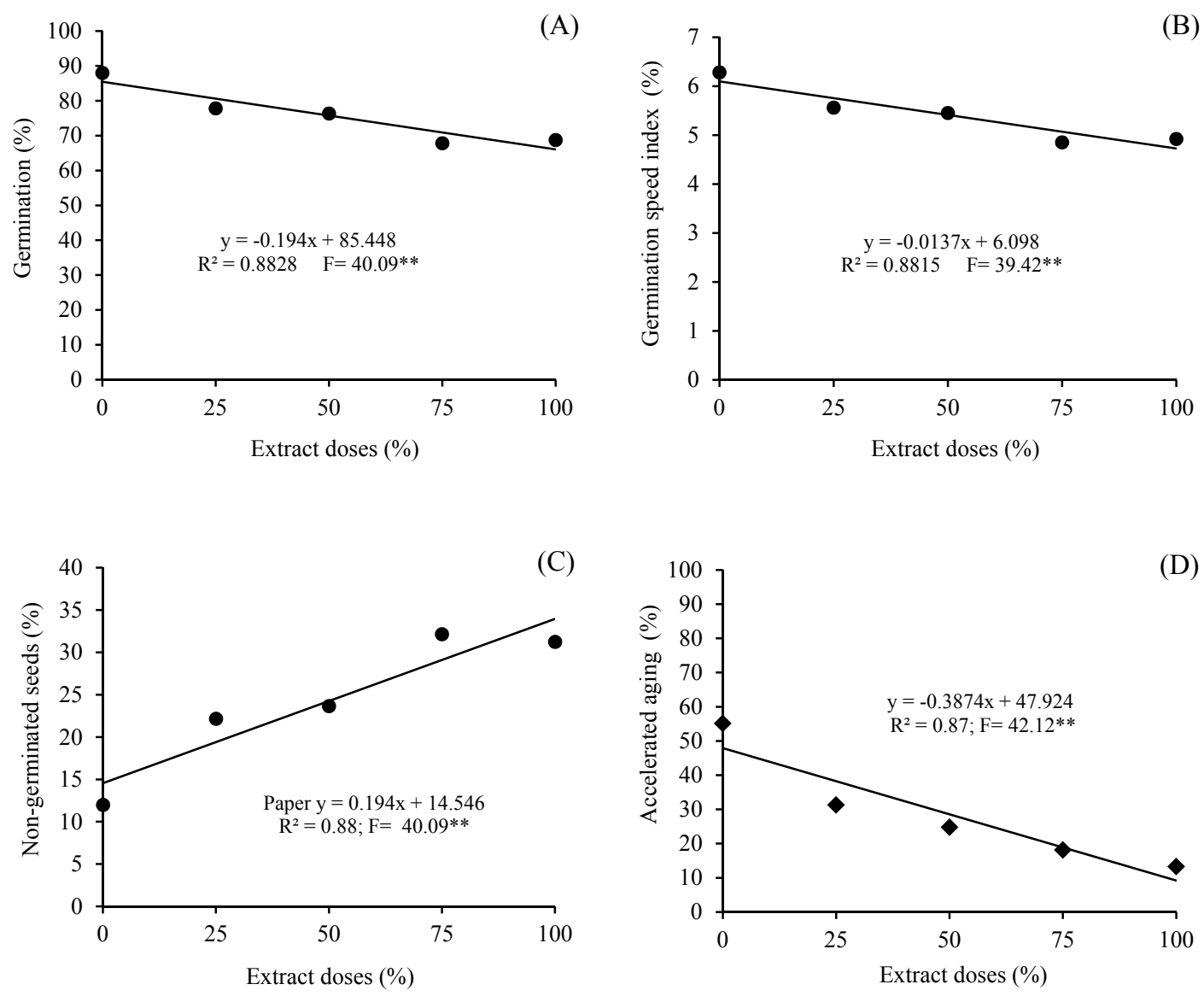

Figure 2. Germination (A), germination speed index (B), non-germinated seeds (C), and accelerated aging (D) in function of concentrations of purple nutsedge extract in tomato

Note. ${ }^{* *}$ Significant by $\mathrm{F}$ test $(\mathrm{P}<0.01)$.

\subsection{Cabbage}

The analysis of variance for all evaluated characteristics is shown in Table 3. All characteristics were statistically significant for both sources of variation, with a significant interaction of substrates and concentrations of purple nutsedge extract for the variables germination, normal seedlings, non-germinated seeds, and germination speed index.

For the variables germination and germination speed index, the behavior of the interaction was similar. In these cases, the values fitted a decreasing linear regression for the sand and commercial substrates, and there was no significant effect for the substrate paper (Figures 3A and 3B). The results obtained for these variables confirm the allelopathic effects of purple nutsedge extract. The germination process may be compromised mainly due to the effect of the allelochemicals on membrane permeability, enzyme activity and water relations. According to S. J. H. Rizvi and H. Rizvi (1992), these are some of the effects of these substances on plant cells.

Muniz et al. (2007) observed results similar to those found in the present study. There was a decrease in germination of lettuce seeds with the increase in the concentration of the extract of purple nutsedge. Gomes et al. (2016), evaluating the effects of purple nutsedge extract on lettuce seeds, observed the same behavior for the variables germination and germination speed index. 
Table 3. Summary of analysis of variance of the physiological quality of seeds tested by germination $(G)$, normal seedlings (NS), abnormal seedlings (AS), non-germinated seeds (NGS), germination speed index (GSI), and accelerated aging (AA) in function of substrate and concentration of purple nutsedge extract in cabbage.

\begin{tabular}{llllllll}
\hline \multirow{2}{*}{ Source of Variation } & \multicolumn{7}{c}{ P value } \\
\cline { 2 - 7 } & DF & G & NS & AS & NGS & GSI & AA \\
\hline Substrate (S) & 2 & $<0.01^{* *}$ & $<0.01^{* *}$ & $<0.01^{* *}$ & $<0.01^{* *}$ & $<0.01^{* *}$ & $0.0005^{* *}$ \\
Concentration (C) & 4 & $0.003^{* *}$ & $<0.01^{* *}$ & $0.007^{* *}$ & $0.0034^{* *}$ & $0.002^{* *}$ & $0.0188^{*}$ \\
$\mathrm{~S} \times \mathrm{C}$ & 8 & $0.016^{*}$ & $0.054^{\text {ns }}$ & $0.0056^{* *}$ & $0.0157^{*}$ & $0.015^{*}$ & $0.1944^{\mathrm{ns}}$ \\
\cline { 2 - 7 } & \multicolumn{7}{c}{ Mean squares } \\
Residue & 45 & 39.86 & 18.86 & 28.11 & 39.86 & 0.40 & 3.67 \\
Means & - & 43.53 & 25.76 & 17.76 & 56.46 & 4.35 & 4.16 \\
CV $(\%)$ & - & 14.50 & 16.85 & 29.84 & 11.18 & 14.31 & 36.02 \\
\hline
\end{tabular}

Note. * Significant by $\mathrm{F}$ test $(\mathrm{P}<0.05) ; * *$ Significant by $\mathrm{F}$ test $(\mathrm{P}<0.01) ;{ }^{\text {ns }}$ not significant.

For the variables germination and germination speed index, the behavior of the interaction was similar. In these cases, the values fitted a decreasing linear regression for the sand and commercial substrates, and there was no significant effect for the substrate paper (Figures 3A and 3B). The results obtained for these variables confirm the allelopathic effects of purple nutsedge extract. The germination process may be compromised mainly due to the effect of the allelochemicals on membrane permeability, enzyme activity and water relations. According to S. J. H. Rizvi and H. Rizvi (1992), these are some of the effects of these substances on plant cells.

Muniz et al. (2007) observed results similar to those found in the present study. There was a decrease in germination of lettuce seeds with the increase in the concentration of the extract of purple nutsedge. Gomes et al. (2016), evaluating the effects of purple nutsedge extract on lettuce seeds, observed the same behavior for the variables germination and germination speed index.

Andrade et al. (2008) verified that the aqueous extracts of dried leaves reduced the germination percentage of cabbage only at the last concentrations 90 and 100\%, compared to the control treatment, obtaining reductions of 57.1 in both cases. Gusman et al. (2012), evaluating the effects of several allelopathic extracts, found that cabbage seeds exerted an allelopathic effect with the use of the aqueous extract of purple nutsedge, leading to a decrease in germination from the concentration $50 \%$ of the extract. These same authors, testing aqueous extracts of $C$. rotundus on tomato and arugula, found that the germination rate was influenced by the extract of this invasive plant from the concentration $30 \%$ when compared to the control treatment.

The abnormal seedlings showed a significant interaction effect only for the paper substrate. It fitted a linear regression (Figure 3C), showing that the percentage of abnormalities increases with the increase in the concentration of the extract in this substrate. This can be explained because the allelochemical compounds may induce the appearance of abnormal seedlings. Necrosis of the root system is the most evident symptom of allelopathic effects (Ferreira \& Aquila, 2000; Ferreira, 2004).

For the non-germinated seeds, there was an interaction effect for the sand and commercial substrates. It fitted a linear regression in both cases (Figure 3D), with an interpretation similar to that mentioned for abnormal seedlings. 

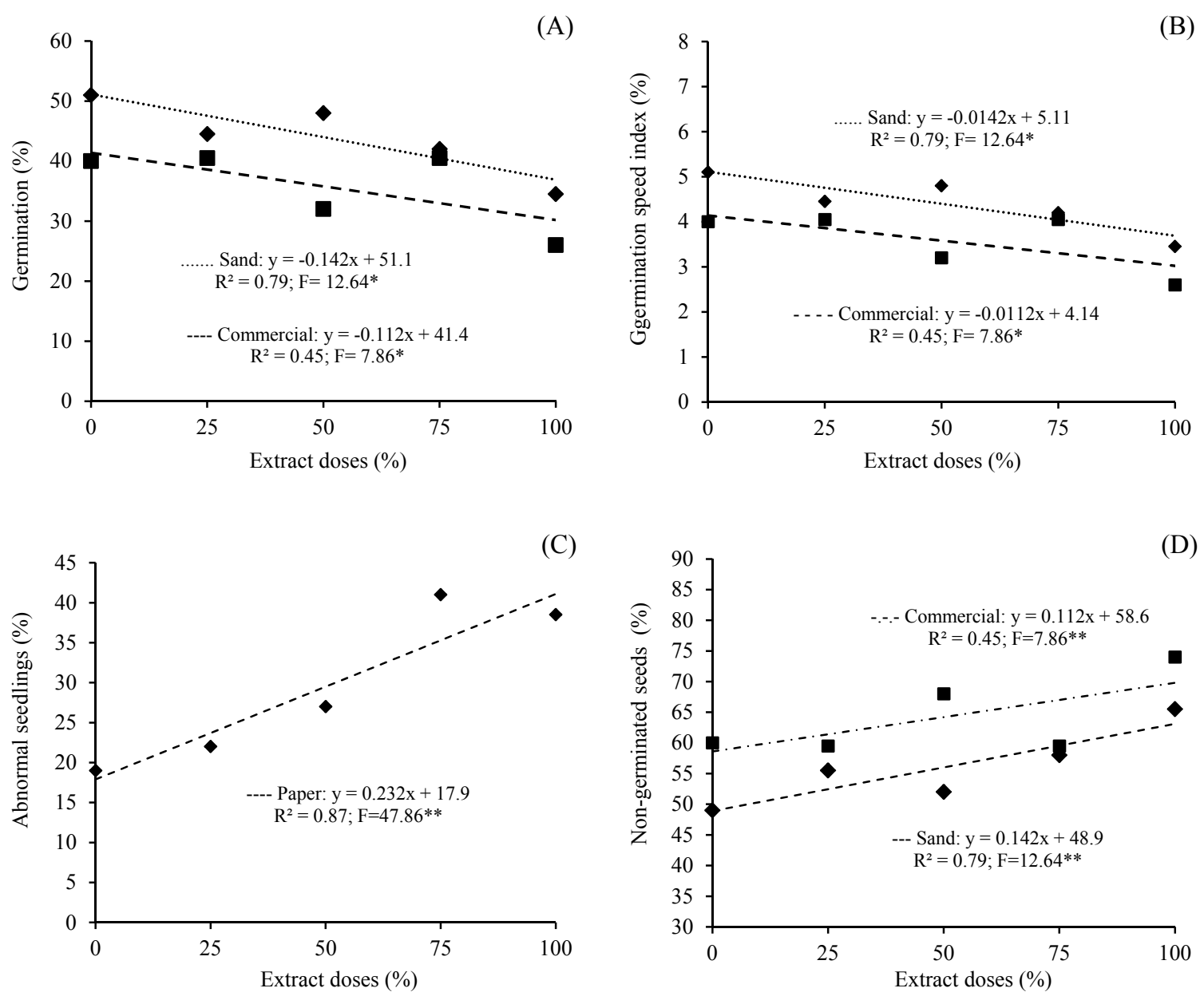

Figure 3. Germination (A), germination speed index (B), abnormal seedlings (C) and non-germinated seeds (D) in function of different substrate types and concentrations of purple nutsedge extract in cabbage

Note. * Significant by $\mathrm{F}$ test $(\mathrm{P}<0.05)$; * Significant by $\mathrm{F}$ test $(\mathrm{P}<0.01)$.

Table 4 shows the mean values of the analyzed variables for the different types of substrates, evaluating the simple effect of this factor. There was a significant effect for all analyzed variables when evaluating the different substrates alone (Table 3).

Table 4. Germination (G), normal seedlings (NS), abnormal seedlings (AS), non-germinated seeds (NGS), germination speed index (GSI), and accelerated aging (AA) in function of substrate and concentration of purple nutsedge extract in cabbage

\begin{tabular}{|c|c|c|c|c|c|c|}
\hline Substrate & G & NS & AS & NGS & GSI & AA \\
\hline & \multicolumn{5}{|c|}{------------------------------ \% ----------------------------- } & ---- \% ---- \\
\hline Paper & $51 \mathrm{a}$ & $2 \mathrm{c}$ & $29 \mathrm{a}$ & $49 \mathrm{a}$ & $5.08 \mathrm{a}$ & $6 \mathrm{~b}$ \\
\hline Commercial & $44 \mathrm{~b}$ & $30 \mathrm{a}$ & $14 \mathrm{~b}$ & $56 \mathrm{~b}$ & $4.40 \mathrm{~b}$ & $10 \mathrm{a}$ \\
\hline Sand & $36 \mathrm{c}$ & $26 \mathrm{~b}$ & $10 \mathrm{c}$ & $64 \mathrm{c}$ & $3.58 \mathrm{c}$ & $10 \mathrm{a}$ \\
\hline F Value & 28.30 & 20.10 & 76.54 & 28.30 & 28.30 & 9.68 \\
\hline $\mathrm{CV}(\%)$ & 14.50 & 16.85 & 29.84 & 11.18 & 14.31 & 36.02 \\
\hline
\end{tabular}

Note. Means followed by the same lowercase letter in columns do not differ by Tukey test at $5 \%$ probability.

Contrary to that observed for tomato seeds, the paper substrate was superior regarding abnormal seedlings, non-germinated seeds and germination speed index for germination in relation to the other substrates used for cabbage seeds (Table 4). This can be explained by the fact that seeds may present differences in their chemical 
composition, embryo position and structure of the integument, which allow the absorption of water from different substrates. According to ISTA (2018), the choice of substrate may vary among species and depends mainly on the size of the seed, the requirement regarding the volume of water, sensitivity to light, and the ease that it offers for seedling evaluation.

The commercial substrate was superior to the other substrates tested only for normal seedlings and accelerated aging. The substrate sand was statistically equal to the commercial substrate.

When evaluating the effects of purple nutsedge extract concentrations alone, there was a significant effect only for the variables normal seedlings and accelerated aging (Figure 4). They fitted a decreasing non-linear regression (Figure 4A and 4B) in both cases, evidencing that as the concentrations of purple nutsedge extract increased, both variables analyzed decreased.
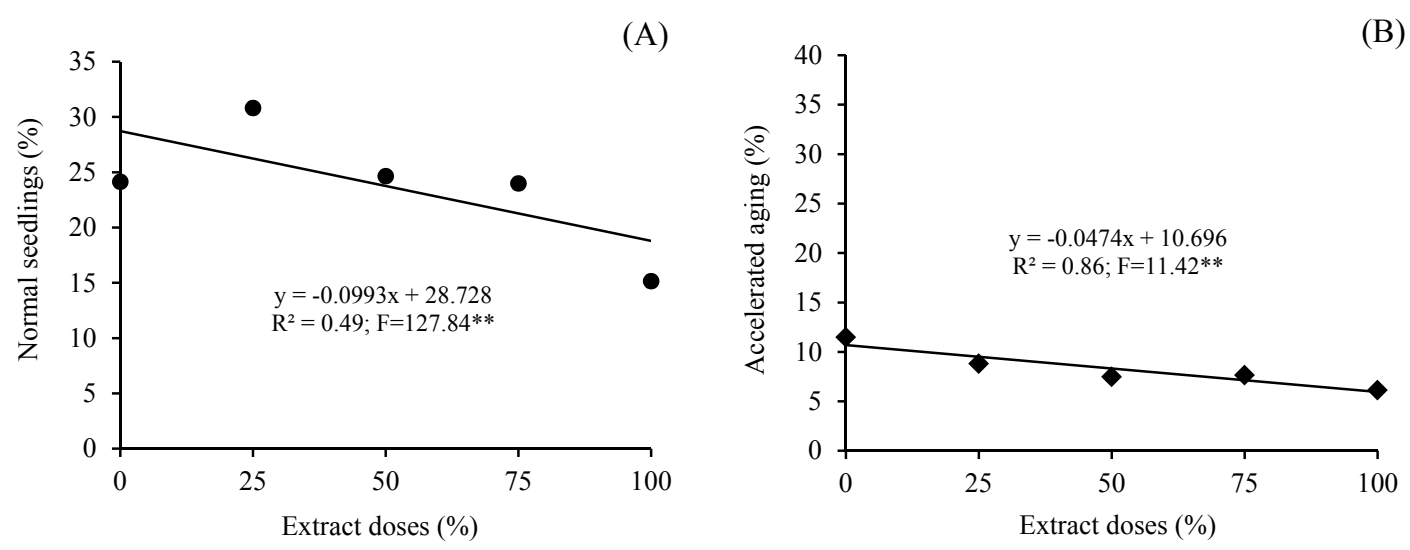

Figure 4. Normal seedlings (A) and accelerated aging (B) in function of concentrations of purple nutsedge extract in cabbage

Note. ** Significant by $\mathrm{F}$ test $(\mathrm{P}<0.01)$.

\section{Conclusion}

Cyperus rotundus presents allelopathic effects on the germination of tomato and cabbage seeds. As the concentration of the tuber extract increases, the inhibitory effect increases, thus reducing germination and seed vigor in the different types of substrates.

The commercial substrate and the paper substrate may minimize the allelopathic effects of Cyperus rotundus extract during germination of tomato and cabbage seeds, respectively.

\section{Acknowledgements}

To the Goiano Federal Institute (Instituto Federal Goiano) (IF Goiano), Campus Urutaí and To the State University of Goiás (Universidade Estadual de Goiás) (UEG), Campus Ipameri for the support in the conduction of the project. To the Group of Study and Research in Phytotechnics (GEPFi).

\section{References}

Andrade, H. M., Bittencourt, A. H. C., \& Vestena, S. (2009). Potencial alelopático de Cyperus rotundus L. sobre espécies cultivadas. Ciência e Agrotecnologia, 33, 1984-1990. https://doi.org/10.1590/S1413-70542009 000700049

Bianchi, M. A. (1995). Programa de difusão do manejo integrado de plantas daninhas em soja no Rio Grande do Sul (p. 31). Cruz Alta: FUNDACEP FECOTRIGO.

Bolzan, F. H. C. (2003). Estudo do efeito alelopático e de identificação de compostos presentes na tiririca (Cyperus rotundus L.) (Relatório Técnico de Pesquisa). Lavras: UFLA/FAPEMIG.

Castro, P. R. C., Rodrigues, J. D., Moraes, M. A., \& Carvalho, V. L. M. (1983). Efeitos alelopáticos de alguns extratos vegetais na germinação do tomateiro (Lycopersicum esculentum Mill. cv. Santa Cruz). Planta Daninha, 6(2), 79-85. https://doi.org/10.1590/S0100-83581983000200001 
Coelho, F. M., Oliveira, S. G., Baliza, D. P., \& Campos, A. N. R. (2014). Efeito de extratos de plantas espontâneas na germinação e no crescimento inicial do feijão comum. Revista Brasileira de Agroecologia, 9(2), 185-192.

Cunha, A. M., Cunha, G. M., Sarmento, R. A., Cunha, G. M., \& Amaral, J. F. T. (2006). Efeito de diferentes substratos sobre o desenvolvimento de mudas de Acacia sp. Revista Árvore, 30(2), $207-214$. https://doi.org/10.1590/S0100-67622006000200007

Durigan, J. C., Correia, N. M., Timossi, P. C. (2005). Estádios de desenvolvimento e vias de contato e absorção dos herbicidas na inviabilização de tubérculos de Cyperus rotundus. Planta Daninha, 23, 621-626.

Ferreira, A. G. (2004). Interferência: Competição e alelopatia. In A. G. Ferreira, \& F. Borghetti (Eds.), Germinação: Do básico ao aplicado (pp. 251-262). Porto Alegre: Artmed.

Ferreira, A. G., \& Aquila, M. E. A. (2000). Alelopatia: uma área emergente da ecofisiologia. Revista Brasileira de Fisiologia Vegetal, 12(Edição Especial), 175-204.

Gomes, I. S., Oliveira, C. S., Pelosi, A. P., Pacheco, L. C. P. S., Benett, C. G. S., \& Benett, K. S. S. (2016). Evaluation of physiological quality of lettuce and rocket salad seeds in the presence of purple nuts edget extract. African Journal of Agricultural Research, 11(21), 1887-1893. https://doi.org/10.5897/AJAR2016. 10956

Gusman, G. S., Vieira, L. R., \& Vestena, S. (2012). Alelopatia de espécies vegetais com importância farmacêutica para espécies cultivadas. Biotemas, 25(4), 37-48. https://doi.org/10.5007/2175-7925. 2012v25n4p37

Hartmann, H. T., Kester, D. E., Davies Junior, F. T., \& Geneve, R. L. (1997). Plant propagation: Principles and practices (6th ed., p. 770). New Jersey: Prentice Hall International.

Henning, A. A. (1994). Patologia de sementes (p. 43). Londrina: Embrapa Soja.

ISTA (International Seed Testing Association). (2018). The germination test. ISTA, International Rules for Seed Testing (pp. 5.5-5.56). Bassersdorf: ISTA.

Jakelaitis, A., Ferreira, L.R., Silva, A. A., Agnes, E. L., Miranda, G. V., \& Machado, A. F. L. (2003). Efeitos de sistemas de manejo sobre a população de tiririca. Planta Daninha, 21(1), 89-95. https://doi.org/10.1590/ S0100-83582003000100011

Maguire, J. D. (1962). Speed of germination aid in selection and evaluation for seedling emergence and vigor. Crop Science, 2(1), 176-177.

Marcos Filho, J. (1999). Teste de envelhecimento acelerado. In F. C. Kryzanowski, R. D. Vieira, \& J. B. França Neto (Eds.), Vigor de sementes: Conceitos e testes (Cap. 3, pp. 3.1-3.24). Londrina-PR: ABRATES.

Moraes, L. C. A., Garcia, T. B., Sousa, N. R., \& Moreira, A. (2007). Indução de brotação apical em mudas provenientes de sementes e do enraizamento de estacas de mangostãozeiro. Acta Scientiarum. Agronomy, 29(5), 665-669. https://doi.org/10.1590/S1807-86212007000500011

Muniz, F. R., Cardoso, M., Von Pinho, E. V. R., \& Vilela, M. (2007). Qualidade fisiológica de sementes de milho, feijão, soja e alface na presença de extrato de tiririca. Revista Brasileira de Sementes, 29(2), $195-204$. https://doi.org/10.1590/S0101-31222007000200026

Panozzo, L. E., Agostinetto, D., Galon, L., Moraes, P. V. D., Pinto, J. J. O., \& Neves, R. (2009). Métodos de manejo de Cyperus esculentus na lavoura de arroz irrigado. Planta Daninha, 27(1), 165-174. https://doi.org/ 10.1590/S0100-83582009000100021

Pires, N. M., Prates, H. T., Pereira Filho, I. A., Oliveira, R. S., \& Faria, T. C. L. (2001). Atividade alelopática de Leucena sobre espécies de plantas daninhas. Scientia Agrícola, 58(1), 61-65. https://doi.org/10.1590/ S0103-90162001000100011

Rizvi, S. J. H., \& Rizvi, H. (1992). Allelopathy: Basic and applied aspects (pp. 443-472). London: Chapman \& Hall.

Stockman, A. L., Brancalion, P. H. S., Novembre, A. D. L. C., \& Chamma, H. M. C. P. (2007). Sementes de ipê-branco (Tabebuia roseo-alba (Ridl.) Sand-Bignoniaceae): Temperatura e substrato para o teste de germinação. Revista Brasileira de Sementes, 29(3), 139-143.

Souza, I. F., \& Furtado, D. A. S. (2002). Caracterização de aleloquimicos do centeio (Secale cereale) e seu potencial alelopático sobre plantas de alface (Lactuca sativa). Ciência e Agrotecnologia, 26(5), 1097-1099. 
Tokura, L. K., \& Nóbrega, L. H. P. (2006). Alelopatia de cultivos de cobertura vegetal sobre plantas infestantes. Acta Scientiarum Agronomy, 28(3), 379-383.

\section{Copyrights}

Copyright for this article is retained by the author(s), with first publication rights granted to the journal.

This is an open-access article distributed under the terms and conditions of the Creative Commons Attribution license (http://creativecommons.org/licenses/by/4.0/). 